\title{
Anesthesia in a Patient with Diaphragmatic Hernia and Obstructive Sleep Apnea: Case Report
}

\author{
Feriha Temizel, ${ }^{1}$ Tamer Kuzucuoğlu, ${ }^{1}$ Gülten Arslan, ${ }^{1}$ Serkan Uçkun, ${ }^{1}$ \\ Banu Eler Çevik, Recep Demirhan²
}

\begin{abstract}
'Department of Anesthesiology and Reanimation, Health Science University, Kartal Dr. Lütfi Kırdar Kartal Training and Research Hospital, İstanbul, Turkey ${ }^{2}$ Department of Thoracic Surgery, Health Science University, Kartal Dr. Lütfi Kırdar Kartal Training and Research Hospital, İstanbul, Turkey
\end{abstract}

Submitted: 01.11.2017 Accepted: 13.12.2017

Correspondence: Feriha Temizel, Kartal Dr. Lütfi Kırdar Kartal Eğitim ve Araştırma Hastanesi, Anesteziyoloji ve Reanimasyon Kliniği, İstanbul, Turkey

E-mail: ferihatemizel@yahoo.com.tr

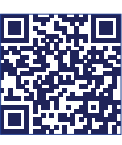

Keywords: Anesthesia; obstructive sleep apnea; traumatic diaphragmatic hernia.

\begin{abstract}
Traumatic diaphragmatic hernia (TDH) is a serious, frequently overlooked complication observed secondary to a thoracoabdominal trauma. The treatment of TDH is surgical and diaphragmatic repair, usually performed with a thoracotomy approach. During a thoracotomy, the lung on the operation side is collapsed and single-lung ventilation is employed. This procedure facilitates the work of the surgeon; however, it makes the administration of anesthesia more difficult. Obstructive sleep apnea (OSA) is a disorder characterized by attacks of apnea and hypopnea due to partial or complete obstruction of the upper respiratory tract during sleep. Administration of anesthesia to patients with OSA involves several difficulties with respect to ventilation and intubation, as well as potential respiratory complications during the postoperative period. In this case report, critical issues faced during the administration of anesthesia to a 46-year-old male patient with OSA who was diagnosed with TDH I year after a trauma were discussed in the context of the literature.
\end{abstract}

\section{INTRODUCTION}

Traumatic diaphragmatic hernia (TDH) is an easily overlooked complication due to well-known but nonspecific clinical and radiological findings of blunt or penetrating thoracoabdominal trauma affecting the diaphragm. ${ }^{[]}$Particularly if there are no other organ injuries in the acute period post trauma, diagnosis may be delayed for months or even years, which increases morbidity and mortality. A thoracotomy approach is preferred in chronic and delayed cases as a result of intrathoracic adhesions that may occur 7 to 10 days after the trauma. ${ }^{[2]}$ During anesthesia management in thoracotomy surgery, single-lung ventilation (SLV) is used. ${ }^{[3]}$ Double-lumen endobronchial tubes are used for intubation, and the patient is laid in the lateral decubitus position with the operation side facing up. The goal in SLV is to apply an appropriate ventilation strategy that does not lead to hypoxemia or hypercapnia.

Obstructive sleep-apnea (OSA) is characterized by recurrent episodes of apnea, a decrease in oxygen saturation, and an increase in daytime sleepiness due to partial or complete obstruction of the upper respiratory tract during sleep at night. ${ }^{[4]}$ Presently described is a case of TDH and OSA, in the context of the literature.

\section{CASE REPORT}

The patient was a 46 -year-old, $1.70-\mathrm{cm}$ tall male weighing $100 \mathrm{~kg}$ with a history of 30 pack-years of cigarette smok- 
ing, snoring at night, and a fall down 2 flights of stairs I year previously. Upon development of dyspnea and pain in his side, he presented at a chest disease polyclinic, where a decrease in right lung sounds was detected. His arterial blood gas $(\mathrm{ABG})$ values in room air were $\mathrm{pH}$ : 7.39, $\mathrm{PO}_{2}$ : $5 \mathrm{I} \mathrm{mmHg}, \mathrm{PCO}_{2}: 61 \mathrm{mmHg}, \mathrm{SpO}_{2}: 84.8 \%$, and respiratory function test results were forced vital capacity (FVC): 1.83 $\mathrm{L}(43 \%)$, forced expiratory volume-one second $\left(\mathrm{FEV}_{1}\right)$ : I.49 L (43\%), FEV,/FVC: $81.4 \%$. Posteroanterior chest $\mathrm{X}$-ray and thoracic tomography revealed a right diaphragmatic hernia and segmental atelectasis of the middle lower lobes of the right lung (Fig. Ia and b). The patient was diagnosed as TDH with OSA. An echocardiogram did not disclose any pathology (ejection fraction: 50\%). A thoracotomy was planned under SLV to repair the TDH. During the preoperative examination to determine his eligibility for SLV, the following were observed: a short neck, mouth opening: $<4 \mathrm{~cm}$, thyromental distance $<6 \mathrm{~cm}$, and sternomental distance: $<12 \mathrm{~cm}$. His Mallampati score was 4 points, so it was assessed as a case of difficult intubation. The operating room was prepared for difficult intubation. An electrocardiogram was performed, arterial blood pressure $(A B P)$ was measured using noninvasive methods, and peripheral oxygen concentration $\left(\mathrm{SpO}_{2}\right)$ was monitored with a spirometer (Beneview T8; Mindray Medical International Co., Ltd., Shenzen, China) with the following results: ABP: $130 / 75 \mathrm{mmHg}$, heart rate: $60 \mathrm{bpm}$, oxygen saturation with masked respiration $\mathrm{SpO}_{2}: 96 \%$ with $100 \% \mathrm{FiO}_{2}$. Venous cannulation was performed through the dorsum of the left hand, and an infusion of isotonic $0.9 \%$ saline was started at a rate of $20 \mathrm{~mL} / \mathrm{kg}$. To induce anesthesia, $2 \mathrm{~m} \mu \mathrm{kg}^{-1}$ fentanyl (Talinat; Vem İlaç Sanayi, Tekirdağ, Turkey), 3 mgkg-I propofol (Fresenius Kabi, Bad Homburg vor der Höhe, Germany), and I $\mathrm{mgkg}^{-1}$ rocuronium (Jecron; Tüm-Ekip İlaç A.Ş., Tuzla, Turkey) were used. A left-sided double-lumen tube (Robertshaw No. 39) was inserted on the second attempt, and mechanical ventilation was initiated (Perseus A500; Draeger Medical GmbH, Lubeck, Germany). The initial ventilator settings were adjusted to volume-controlled mode as follows: tidal volume: 5-6
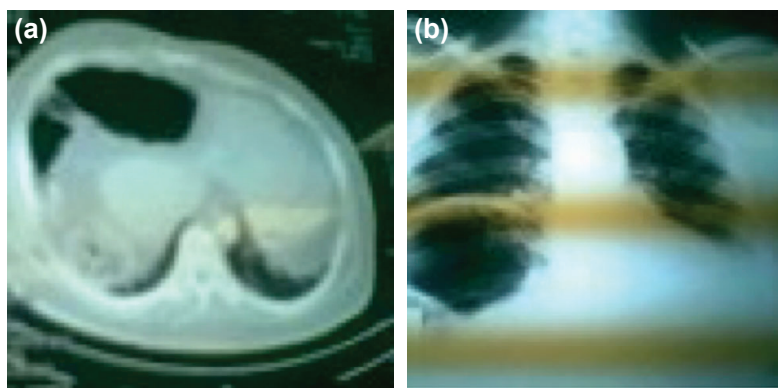

Figure 1. (a) Right diaphragmatic hernia and segmental atelectasis of the middle and lower lobes of the right lung, seen in a computed tomography image. (b) Posteroanterior X-ray showing the right diaphragmatic hernia and segmental atelectasis of the lower middle lobes of the right lung.
$\mathrm{mL} / \mathrm{kg}$, respiratory rate: $14 /$ minute, positive end-expiratory pressure (PEEP): $5 \mathrm{cmH}_{2} \mathrm{O}$, and $\mathrm{FiO}_{2}: 0.3-0.5$. A right internal jugular vein catheter (Seldiflex; Prodimed SAS, Neuilly-en-Thelle, France), a left radial artery cannula (BCAT2; Bıçakcılar Tıbbi Cihazlar A.S., Istanbul, Turkey), and a urethral catheter were inserted. The patient was turned to the left lateral decubitus position. Anesthesia was maintained with $\mathrm{O}_{2}$-air 50\%+l-2\% sevoflurane (Sevorane liquid; Abdi İbrahim Ilaç Sanayi ve Ticaret A.S., İstanbul, Turkey) + remifentanil (Ultiva; GlaxoSmithKline, London, England) (0.I-0.2 $\mu \mathrm{g} / \mathrm{kg} / \mathrm{min})$ delivered by intravenous (IV) route. The surgical team entered the thoracic cavity from the anterior aspect of the liver. The stomach and colon were reduced into the intraabdominal cavity, and the diaphragm was repaired. Intraoperative $A B G$ measurements were $\mathrm{pH}:$ 7.30-7.35, $\mathrm{PCO}_{2}: 55-70 \mathrm{mmHg}, \mathrm{PO}_{2}: 60-85$ $\mathrm{mmHg}$, and $\mathrm{SpO}_{2}: 90-95 \%$. During the 2-hour surgery, his hemodynamic parameters were stable, with $300 \mathrm{~mL}$ blood loss and $250 \mathrm{~mL}$ urine output. At the end of the operation, positive pressure ventilation with $30 \mathrm{~cm} \mathrm{H}_{2} \mathrm{O}$ was applied to expand the collapsed left lung. When skin suturing was initiated, $100 \mathrm{mg}$ tramadol (Abdi İbrahim Ilaç Sanayi ve Ticaret A.S., İstanbul, Turkey), I g paracetamol (Parol, Atabay İlaç Fabrikası A.Ş., İstanbul, Turkey) IV, and intramuscular 10 mg diclofenac sodium (Dikloron; Deva Holding, İstanbul, Turkey) were administered for postoperative analgesia. The patient was extubated without difficulty. Postoperatively, $\mathrm{O}_{2}$ was delivered with a mask at a rate of 2/L/minute with resultant values of $\mathrm{pH}: 7.31, \mathrm{PCO}_{2}: 68$ $\mathrm{mmHg}, \mathrm{PO}_{2}: 87 \mathrm{mmHg}$, and $\mathrm{SpO}_{2}: 95.4 \%$. The patient was transferred to the intensive care unit for close monitoring. Hypoxia and hypercarbia developed, so intermittent noninvasive continuous positive airway pressure (CPAP) ( $\mathrm{FiO}_{2}: 40 \%$, PEEP: $5 \mathrm{cmH}_{2} \mathrm{O}$, and PS: $10 \mathrm{cmH}_{2} \mathrm{O}$ ) treatment was applied. The patient's general state of health improved on the second day. Since ABG parameters were within normal limits ( $\mathrm{pH}: 7.40 \mathrm{mmHg}, \mathrm{PaCO}_{2}: 48 \mathrm{mmHg}, \mathrm{PO}_{2}: 98$ $\mathrm{mmHg}$, and $\mathrm{SpO}_{2}: 97 \%$ ), and CPAP was not required, he was transferred to the surgery service.

\section{DISCUSSION}

Diagnosis of TDH developing after blunt trauma is frequently delayed, despite sophisticated techniques. If the diaphragmatic defect is small and there is no major organ injury, the diagnosis may be overlooked. However, in subsequent days, problems of intestinal obstruction or respiratory problems may emerge. ${ }^{[5]}$ Shortness of breath is reported to be the most frequently encountered symptom in $\mathrm{TDH}$. Organs herniating through the defect (bowels, liver, or omentum) lead to the emergence of symptoms secondary to pulmonary compression. Since herniated organs prevent pulmonary expansion, atelectasis may develop. ${ }^{[6]}$ Our patient complained of shortness of breath 
and flank pain I year after a trauma, and development of atelectasis was determined in the affected side. Various surgical approaches may be used to treat TDH, such as thoracotomy, laparotomy+thoracotomy, laparotomy, video-assisted thoracic surgery, and laparoscopic surgery. In cases without abdominal injury, generally a thoracotomy is preferred. ${ }^{[2]}$ Regardless of the ventilatory strategy used, there is the risk of hypoxemia in SLV ${ }^{[7]}$ Though hypoxia in SLV is associated with many factors, the most important cause is an increase in transpulmonary shunt with perfusion of the nonventilated and collapsed lung. As a physiological compensatory mechanism, hypoxic pulmonary vasoconstriction reduces blood flow to the nonventilated lung, and reduces hypoxia and intrapulmonary shunt. ${ }^{[8]}$ In our case, severe hypoxia did not develop during SLV, and no deviation in cardiac or respiratory parameters was encountered.

OSA is the most frequently seen respiratory disorder related to sleeping pattern. As a result of the growing aging population and an increase in obesity, the prevalence of OSA is gradually increasing. It has been suggested that $9 \%$ to $24 \%$ of the general population is affected by OSA, and every day these patients are anesthetized with $90 \%$ of them not having been diagnosed..$^{[9]} \mathrm{A}$ group of authors has indicated that most surgical cases with OSA can be diagnosed using routine preoperative screening tests. ${ }^{[10]}$ Diagnosis of our case was established with anamnesis and clinical examination in the chest disease clinic. It is well known that untreated OSA results in increased morbidity and mortality. As a result of underlying comorbidities related to long-term untreated OSA, a predisposition to serious perioperative complications or the ability to cope with these complications may be decreased. Even if OSA is treated, because of the upper respiratory tract pathology and associated obesity, the perioperative risk is greater in these patients when compared with normal individuals. [1, 12] Preoperative evaluation of our patient did not reveal any comorbidity (diabetes, hypertension, heart failure) apart from obesity and OSA.

Another issue that should be taken into consideration during a preoperative examination is the use of sedatives and hypnotic drugs for premedication. In cases of OSA, these drugs depress the central nervous system and the respiratory system, and also increase the tendency for upper respiratory tract obstruction. Great care is recommended in the use of a benzodiazepine as premedication. ${ }^{[13]}$ In our case, we did not use a premedication before the induction of anesthesia due to the presence of OSA and the risk of hypoxia secondary to surgical pathology. Some authors have indicated that since patients with OSA have a tendency for respiratory tract obstruction, muscle relaxants should be antagonized. ${ }^{[14]}$ We used a combination of atropine and neostigmine to antagonize muscle relaxation. After surgery lasting for 2 hours, the patient was extubated without any complication, and he recovered rapidly. Peroperative use of long-acting opioid analgesics (morphine and fentanyl) in patients with OSA has been shown to depress postoperative respiratory reflexes. ${ }^{[15]}$ In this case, we preferred the peroperative use of a shortacting, rapidly eliminated remifentanil infusion with multimodal postoperative analgesia. Due to the frequency of respiratory tract obstruction in patients with OSA, monitoring of respiratory and circulatory functions and longer follow-up of these patients in the recovery room have been recommended. ${ }^{[16]}$ Unexpected cardiac ischemia and death can occur following major surgical interventions in these patients. Intensive care may be required to monitor for postoperative hypoxia, oxygen saturation, and arrhythmias. ${ }^{[17]}$ Use of CPAP aids in opening the respiratory tract, which is collapsed during sleep in patients with OSA. It also improves functional capacity and oxygenation, by decreasing the respiratory workload. ${ }^{[18]}$ In a study by Gupta et al., ${ }^{[19]}$ the authors observed the development of severe postoperative complications in patients who had not received preoperative CPAP treatment. Postoperatively, we transferred our patient to the intensive care unit due to the risk of hypoxia given that he had undergone thoracic surgery, had OSA, and required CPAP and close hemodynamic monitoring.

In conclusion, in cases with OSA that are undergoing SLV for TDH repair, the risks associated with anesthesia increase. Preoperative evaluation of patients with OSA should not be overlooked. During anesthesia with SLV, the patient's hemodynamic state should be closely followed, and $A B G$ parameters should be measured regularly. The development of peroperative hypoxia or hypercarbia should be prevented. We think that in order to avoid the development of postoperative respiratory complications, the patient should be monitored in the intensive care unit.

\section{Informed Consent}

Informed consent was obtained from the patient.

Peer-review

Internally peer-reviewed.

Authorship Contributions

Concept: F.T., T.K.; Design: F.T., G.A., S.U.; Data collection \&/or processing: F.T., R.D.; Analysis and/or interpretation: F.T., T.K., S.U.; Literature search: F.T., G.A., B.Ç.; Writing: F.T., B.Ç., R.D.; Critical review: F.T., B.Ç., R.D.

\section{Conflict of Interest}

None declared.

\section{REFERENCES}

1. Guner A, Ozkan OF, Bekar Y, Kece C, Kaya U, Reis E. Management of delayed presentation of a right-side traumatic diaphragmatic rupture. World J Surg 2012;36:260-5. [CrossRef]

2. Fangbiao Z, Chunhui Z, Chun Z, Hongcan S, Xiangyan Z, Shaosong 
T. Thoracotomy for Traumatic Diaphragmatic Hernia. Indian J Surg 2016;78:371-4. [CrossRef]

3. McGrath B, Tennuci C, Lee G. The History of One-Lung Anesthesia and the Double-Lumen Tube.J Anesth Hist 2017;3:76-86. [CrossRef]

4. Vasu TS, Grewal R, Doghramji K. Obstructive sleep apnea syndrome and perioperative complications: a systematic review of the literature. J Clin Sleep Med 2012;8:199-207. [CrossRef]

5. Turhan K, Makay O, Cakan A, Samancilar O, Firat O, Icoz G, et al. Traumatic diaphragmatic rupture: look to see. Eur J Cardiothorac Surg 2008;33:1082-5. [CrossRef]

6. Peer SM, Devaraddeppa PM, Buggi S. Traumatic diaphragmatic hernia-our experience. Int J Surg 2009;7:547-9. [CrossRef]

7. Chigurupati K, Raman SP, Pappu UK, Madathipat U. Effectiveness of ventilation of nondependent lung for a brief period in improving arterial oxygenation during one-lung ventilation: A prospective study. Ann Card Anaesth 2017;20:72-5. [CrossRef]

8. Karzai W, Schwarzkopf K. Hypoxemia during one-lung ventilation: prediction, prevention, and treatment. Anesthesiology 2009;110:1402-11. [CrossRef]

9. Peppard PE, Young T, Barnet JH, Palta M, Hagen EW, Hla KM. Increased prevalence of sleep-disordered breathing in adults. Am J Epidemiol 2013;177:1006-14. [CrossRef]

10. Mutter TC, Chateau D, Moffatt M, Ramsey C, Roos LL, Kryger M. A matched cohort study of postoperative outcomes in obstructive sleep apnea: could preoperative diagnosis and treatment prevent complications? Anesthesiology 2014;121:707-18. [CrossRef]

11. Abdelsattar ZM, Hendren S, Wong SL, Campbell DA, Jr, Ramachandran SK. The impact of untreated obstructive sleep apnea on car- diopulmonary complications in general and vascular surgery: a cohort study. Sleep 2015;38:1205-10. [CrossRef]

12. Arisaka H, Sakuraba S, Kobayashi R, Kitahama H, Nishida N, Furuya $\mathrm{M}$, et al. Perioperative management of obstructive sleep apnea with nasal continuous positive airway pressure. Anesth Prog 2008;55:121-3.

13. Ankichetty S, Wong J, Chung F. A systematic review of the effects of sedatives and anesthetics in patients with obstructive sleep apnea.J Anaesthesiol Clin Pharmacol 2011;27:447-58. [CrossRef]

14. Arisaka H, Sakuraba S, Kobayashi R, Kitahama H, Nishida N, Furuya $\mathrm{M}$, et al. Perioperative management of obstructive sleep apnea with nasal continuous positive airway pressure. Anesth Prog 2008;55:121-3.

15. Fassbender P, Herbstreit F, Eikermann M, Teschler H, Peters J. Obstructive Sleep Apnea-a Perioperative Risk Factor. Dtsch Arztebl Int 2016;113:463-9.

16. Liu F, Liu L, Zheng F, Tang X, Bao Y, Zuo Y. Identification of surgical patients at high risk of OSAS using the Berlin Questionnaire to detect potential high risk of adverse respiratory events in post anesthesia care unit. Front Med 2017 Jun 7 [Epub ahead of print], doi: 10.1007/ s11684-017-0533-8. [CrossRef]

17. Ambrosii T, Şandru S, Beliii A. The prevalence of perioperative complications in patients with and without obstructive sleep apnoea: a prospective cohort study. Rom J Anaesth Intensive Care 2016;23:103-10.

18. Hillman DR, Loadsman JA, Platt PR, Eastwood PR. Obstructive sleep apnoea and anaesthesia. Sleep Med Rev 2004;8:459-71. [CrossRef]

19. Liao P, Yegneswaran B, Vairavanathan S, Zilberman P, Chung F. Postoperative complications in patients with obstructive sleep apnea: a retrospective matched cohort study. Can J Anaesth 2009;56:819-28.

\section{Diyafragma Hernisi ve Obstrüktif Uyku Apsesi Olan Hastada Anestezi: Olgu Sunumu}

Travmatik diyafragma hernisi (TDH) torakoabdominal travmalardan sonra görülen ve kolaylıkla atlanılabilen komplike bir durumdur. TDH'nin tedavisi cerrahidir ve operasyonda torakotomi yaklaşımı ile diyafragma onarımı yapılır. Torakotomide tek akciğer ventilasyonu ile ameliyat edilen taraftaki akciğer kollabe edilir. Bu durum cerrahın işini kolaylaştırırken anestezi uygulamasını zorlaştırmaktadır. Obstrüktif uyku apne sendromu (OUAS); uyku sırasında üst hava yolunda kısmi ya da tam obstrüksiyon sonucu apne ve hipoapne ataklarının görüldüğü bir hastalıktır. Obstrüktif uyku apne sendromlu olgularda anestezi uygulaması; ventilasyon ve entübasyonun güç olması ayrıca ameliyat sonrası dönemde solunum problemleri görülebilmesi gibi özellikleri içermektedir. Biz bu olgu sunumunda geçirdiği travmadan bir yıl sonra TDH tanısı konulan OUAS'li 46 yaşında erkek hastanın anestezi uygulamasında karşılaştı̆̆ımız önemli konuları literatür eşliğinde tartışmayı amaçladık.

Anahtar Sözcükler: Anestezi; obstrüktif uyku apne sendromu, travmatik diyafragma hernisi. 